\title{
Detailed modeling of two diode photovoltaic module using MATLAB simulik
}

\author{
Habbati Bellia Assia ${ }^{1}$, Moulay Fatima ${ }^{2}$ \\ ${ }^{1}$ Tahri Mohamed University Bechar, Energarid Laboratory, Algeria \\ ${ }^{2}$ Sidi Bel-Abbes University, IRECOM Laboratory, Algeria
}

\begin{tabular}{l}
\hline Article Info \\
\hline Article history: \\
Received Nov 10, 2018 \\
Revised Feb 12, 2019 \\
Accepted Apr 10, 2019 \\
\hline
\end{tabular}

Keywords:

Two diode model

DC/DC converter

MPPT

Duty cycle

Matlab/Simulink

\begin{abstract}
This paper proposes an accurate model of Photovoltaic Module. The model is presented in details and simulated by Matlab Simulink. The PV module is presented as a two diode model with the series' and parallels' resistances. The method is used to obtain the parameters of the module by using data provided by the manufacturer. To verify the accuracy of the proposed model, a comparison is done between the present results and those in a previous paper in which the single diode detailed model was studied. The same type of modules (PWX 500) is used to compare and validate results. The weather data as illumination and temperature are taken as input variables when current and Power are output variables. For the validation of the proposed model, it is used to power a resistive load by using a boost converter controlled by à Maximum Power Point Tracking method. The proposed method is very detailed and can be useful for PV researchers for their works
\end{abstract}

Copyright $(0) 2019$ Institute of Advanced Engineering and Science. All rights reserved.

\section{Corresponding Author:}

Habbati Bellia Assia,

Department of Science and Technology

Tahri Mohammed University, Béchar 8000 Algeria

Email: bellia_abdeljalil@yahoo.fr

\section{INTRODUCTION}

Electricity generated from fossil fuels which are based on oil and gas represents more than $60 \%$ of the world production. Until today, it remains the basis for electricity production. But it is also the first source of pollution. In addition to this, the traditional organization of the electrical system (production, transport, distribution) is seen over the decades, attenuated because of two key phenomena; population growth and change of the load quality which contains now more polluting devices such as computing devices for example.

Renewable energy is needed nowadays as an alternative to fossil energy in depletion. Repetitive natural phenomena as sunlight, wind and wave offer to us a very good opportunity to recover the clean aspect of our planet. In recent decades, many researchers are working on the PV cell technology and its efficiency. The electric power generated by the PV module depends strongly on irradiance and temperature.

The photovoltaic cell is the basic device which generates electricity from sunlight. Cells are grouped in series to increase voltage or in parallel to increase current. Modules and arrays are formed by the cited association of cells. The PV cell is presented by an equivalent circuit elaborated according to the fundamentals of semi conductors. The simplest model is an ideal equivalent circuit made of a current source in parallel with a diode as shown in Figure 1 [1] and which doesn't take in consideration many parameters related to fabrication processes or to the materials

A practical model includes a resistance Rs in series with the current source as in [2-6]. $R_{S}$ is responsible for the reduction in output voltage [7]. However, this model exhibits serious deficiencies when subjected to temperature variations. A most practical model adds another resistance $R_{p}$ in parallel with the diode as in [7-11]. $R_{P}$ reduces the output current of the module because of the leakage current through the 
parallel branch [7]. But the most accurate model is the Two Diode $R_{s} R_{p}$ model $[12,13]$ as shown in Figure 2.

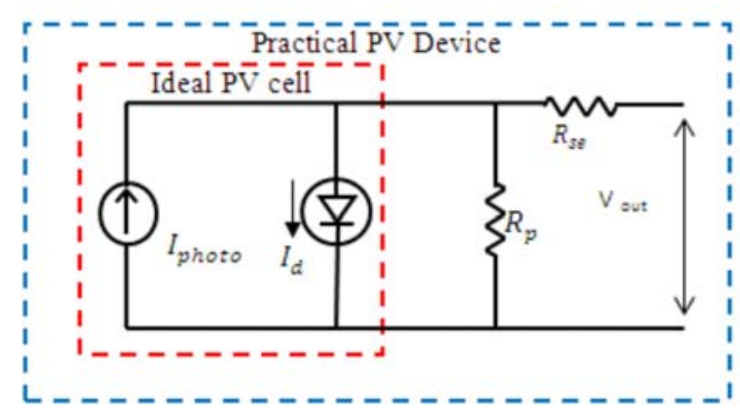

Figure 1. PV cell equivalent circuits [1]

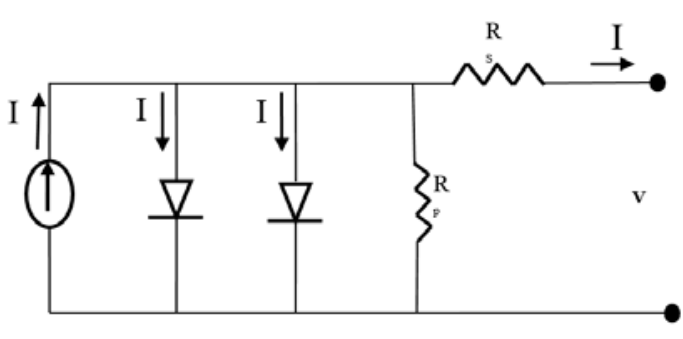

Figure 2. Two Diode model of PV cell

As manufacturers don't give enough information on data sheets about the parameters which depend on weather conditions (illumination and temperature), some assumptions are necessary to establish a mathematical model of the PV cell and the PV module. After modeling the PV cell, the optimal power can be determined accurately with the mathematical model so that it matches with the experimental data. $\mathrm{I}(\mathrm{V})$ characteristic is a non-linear (Transcendental) equation with several parameters. Some of them are provided by constructors but have to be adjusted, and others must be computed in the present work as $R_{P}$, reverse saturation currents of the two diodes $I_{S 1}$ and $I_{S 2}$, and their ideal factors $A_{1}$ and $A_{2}$. The objective of our work is to determine the parameters and simulate the module with these settings in order to compare the power generated by simulation with the one obtained experimentally and delivered by the constructor. Then, the PV module is connected with a load via a DC/DC converter

\section{PRESENTATION AND MODELING OF PV MODULE}

\subsection{One Diode PV model} ideal model:

The red part of Figure 1 shows that the Kirchhoff law allows obtaining the output current I for the

$$
I=I_{p h}-I_{d}
$$

Where $I_{p h}$ is the photocurrent, $I_{d}$ the Diode current which is given by (2):

$$
I_{d}=I_{S}\left[e^{\frac{V}{A \cdot N_{S} \cdot V_{T}}}-1\right]
$$

Where $\mathrm{V}$ is the voltage imposed to the diode, $\mathrm{V}_{\mathrm{T}}$ the thermal voltage and equal to $\left(\mathrm{k} . \mathrm{T}_{\mathrm{C}} / \mathrm{q}\right), \mathrm{T}_{\mathrm{C}}$ is the cell temperature in Kelvin $(\mathrm{K}), \mathrm{k}$ is the Boltzmann constant $\left(1,381.10^{-23} \mathrm{j} / \mathrm{K}\right)$, $\mathrm{q}$ is electron charge $\left(1.602 .10^{-19} \mathrm{C}\right)$, Ns is the number of cell connected in series, A the ideality factor and Is the reverse saturation current.

The presence of the series resistance changes the diode current into the following form:

$$
I_{d}=I_{S}\left[e^{\frac{q\left(V+I . R_{S}\right)}{A \cdot N_{S} \cdot k \cdot T_{c}}}-1\right]
$$

The bleu part of Figure 1 shows the most practical One Diode model. The output current is also obtained by Kirchhoff law and written in (4):

$$
I=I_{p h}-I_{d}-I_{p}
$$

Where $I_{P}$ is the current of leak in parallel resistance $R_{P}$.

According to the previous equation, the output current of the One Diode module with $\mathrm{N}_{\mathrm{S}}$ cells in series is:

Int J Pow Elec \& Dri Syst, Vol. 10, No. 3, Sep 2019 : $1603-1612$ 


$$
I=I_{p h}-I_{S}\left[e^{\frac{q\left(V+I \cdot R_{S}\right)}{A \cdot N_{S} \cdot k \cdot T_{C}}}-1\right]-\frac{V+I R_{S}}{R_{p}}
$$

\subsection{Two Diode PV model}

The most accurate model is presented in Figure 2. It is also called "Two exponentials model". It is given as:

$$
I=I_{p h}-I_{s 1}\left[e^{\frac{q\left(V+I . R_{S}\right)}{A_{1} \cdot N_{S} \cdot k \cdot T_{C}}}-1\right]-I_{S 2}\left[e^{\frac{q\left(V+I \cdot R_{S}\right)}{A_{1} \cdot N_{S} \cdot k \cdot T_{c}}}-1\right]-\frac{V+I R_{S}}{R_{p}}
$$

\section{DETERMINATION OF THE PARAMETERS}

Seven parameters must be determined $I_{p h}, I_{S 1}, I_{S 2}, R_{s}, R_{p}, A_{1}$, and $A_{2}$. But as $A_{1}$ and $A_{2}$ are assumed, $I_{S 1}$ and $I_{S 2}$ are not determined and Iph is known, the parameters to be determined are only $R_{S}$ and $R_{p}$

- The photocurrent under any conditions depends on irradiance and temperature and $\mathrm{I}_{\mathrm{ph}, \mathrm{ref}}$ :

$$
I_{p h}=\frac{G}{G_{r e f}}\left(I_{p h, r e f}+k_{i} . \Delta T\right)
$$

Where $\mathrm{I}_{\mathrm{ph}, \mathrm{ref}}(\mathrm{A})$ is the photocurrent at $\mathrm{STC}$ and $\mathrm{G}$ is the Irradiance called also illumination $\left(\mathrm{W} / \mathrm{m}^{2}\right)$, $G_{\text {ref }}$ : Irradiance at $\mathrm{STC}=1000 \mathrm{~W} / \mathrm{m}^{2}, \Delta T=T_{c}-T_{c, \text { ref }}$ (Kelvin), $T_{c, \text { ref }}$ is the cell temperature at $\mathrm{STC}=25+273=298 \mathrm{~K}, k_{i}$ is the coefficient temperature of short circuit current $(\mathrm{A} / \mathrm{K})$, provided by the manufacturer.

- The reverse saturation current for each diode is given by the following expressions[19]:

$$
\begin{aligned}
& I_{s 1}=I_{s c, r e f} \cdot \exp \left(\frac{-q \cdot V_{o c, r e f}}{A_{1} \cdot N_{S} \cdot k \cdot T_{C}}\right)\left(\frac{T_{C}}{T_{c, r e f}}\right)^{3} \exp \left[\left(\frac{q \cdot \varepsilon_{G}}{A_{1} \cdot k}\right)\left(\frac{1}{T_{c, r e f}}-\frac{1}{T_{c}}\right)\right] \\
& I_{s 2}=I_{s c, r e f} \cdot \exp \left(\frac{-q \cdot V_{o c, r e f}}{A_{2} \cdot N_{S} \cdot k \cdot T_{C}}\right)\left(\frac{T_{C}}{T_{c, r e f}}\right)^{3} \exp \left[\left(\frac{q \cdot \varepsilon_{G}}{A_{2} \cdot k}\right)\left(\frac{1}{T_{c, r e f}}-\frac{1}{T_{c}}\right)\right]
\end{aligned}
$$

- $\mathrm{A}_{1}$ is the ideality factor of the first diode according to the diffusion current densities.

- $\mathrm{A}_{2}$ is the ideality factor of the second diode according to recombination current density [17].

Most of papers on two diode model of PV cell assumed that $A_{1}=1$ and $A_{2}=2[7,8,13]$.

In the proposed model, $\mathrm{A}_{1}=1$ and $\mathrm{A}_{2}=1.2$ because when plotting $\mathrm{P}(\mathrm{V})$ characteristics, the best match is obtained with the practical model provided in manufacturer data sheet [14-18], and (6) is now rewritten at maximum power condition (according to data sheet):

$$
I_{\text {max }, \text { ref }}=\frac{P_{\text {max }, \text { ref }}}{V_{\text {max }, \text { ref }}}=I_{p h, \text { ref }}-I_{d 1}-I_{d 2}-\left[\frac{\left(V_{\text {max }, r e f}+R_{S} \cdot I_{\text {max }, r e f}\right)}{R_{p}}\right]
$$

$\mathrm{R}_{S}$ is varied to compute $\mathrm{R}_{\mathrm{P}}$ in (6) which is implemented in Matalb Simulink environment. The iteration starts at $R_{S}=0$ and increases in order to force the computed max power point moving until it matches with the experimental max power point. The corresponding $\mathrm{R}_{\mathrm{P}}$ is then deduced. Finally, only one pair $\left(R_{P}, R_{S}\right)$ satisfies this condition and its expression at max power is written as follows:

$$
R_{p}=\frac{V_{\max , r e f}+R_{S} \cdot I_{\text {max }, \text { ref }}}{I_{p h, r e f}-I_{S 1}\left[e^{\frac{q\left(V+I . R_{S}\right)}{A_{1} \cdot N_{S} \cdot k \cdot T_{c}}}-1\right]-I_{S 2}\left[e^{\frac{q\left(V+I . R_{S}\right)}{A_{1} \cdot N_{S} \cdot k \cdot T_{c}}}-1\right]-\frac{P_{\max , r e f}}{V_{\max , r e f}}}
$$

The PWX 500 PV module (49W) is used to validate the proposed model. The series resistance $\mathrm{R}_{\mathrm{S}}$ is provided equal to $0.55 \Omega$ but $R_{P}$ is not given as seen in Table 1 . Results of the One Diode Model, previously given in detail in [19], are given now in table to be compared with results of the Two Diode Model and with the provided data at STC.

Table 1. PWX 500 PV module (49W) characteristics at $25^{\circ} \mathrm{C}, 1.5 \mathrm{AM}, 1000 \mathrm{~W} / \mathrm{m}^{2}$ 


\begin{tabular}{cccc}
\hline & Provided parameters & $\begin{array}{c}\text { Adjusted parameters for } \\
\text { One Diode Model }\end{array}$ & $\begin{array}{c}\text { Adjusted parameters for } \\
\text { Two Diode Model }\end{array}$ \\
\hline $\mathrm{P}_{\max }$ & $49 \mathrm{~W}$ & $49 \mathrm{~W}$ & $49 \mathrm{~W}$ \\
$\mathrm{I}_{\mathrm{mp}}$ & $2.88 \mathrm{~A}$ & $2.88 \mathrm{~A}$ & $2.88 \mathrm{~A}$ \\
$\mathrm{~V}_{\mathrm{mp}}$ & $17 \mathrm{~V}$ & $17 \mathrm{~V}$ & $17 \mathrm{~V}$ \\
$\mathrm{I}_{\mathrm{sc}}$ & $3.11 \mathrm{~A}$ & $3.11 \mathrm{~A}$ & $3.11 \mathrm{~A}$ \\
$\mathrm{~V}_{\mathrm{oc}}$ & $21.8 \mathrm{~V}$ & $21.8 \mathrm{~V}$ & $21.8 \mathrm{~V}$ \\
$\mathrm{R}_{\mathrm{S}}$ & $0.55 \Omega$ & $0.45 \Omega$ & $0.3 \Omega$ \\
$\mathrm{R}_{\mathrm{P}}$ & - & $310 \Omega$ & $200 \Omega$ \\
$\mathrm{A}_{1}$ & - & 1.3 & 1 \\
$\mathrm{~A}_{2}$ & - & - & 1.2 \\
$\mathrm{I}_{\mathrm{S} 1}$ & - & $4.116^{*} 10^{-8} \mathrm{~A}$ & $1.782^{*} 10^{-10} \mathrm{~A}$ \\
$\mathrm{I}_{\mathrm{S} 2}$ & - & - & $9.075^{*} 10^{-9} \mathrm{~A}$ \\
$\mathrm{Noct}_{\mathrm{N}}$ & $45 \mathrm{C}^{\circ}$ & $45 \mathrm{C}^{\circ}$ & $45 \mathrm{C}$ \\
$\mathrm{K}_{\mathrm{i}}$ & $1.3 * 10-3\left(/ \mathrm{K}^{\circ}\right)$ & $1.3 * 10-3\left(/ \mathrm{K}^{\circ}\right)$ & $1.3 * 10-3\left(/ \mathrm{K}^{\circ}\right)$ \\
$\mathrm{K}_{\mathrm{v}}$ & $-72.5^{*} 10-3\left(/ \mathrm{K}^{\circ}\right)$ & $-72.5^{*} 10-3\left(/ \mathrm{K}^{\circ}\right)$ & $-72.5^{*} 10-3\left(/ \mathrm{K}^{\circ}\right)$ \\
$\mathrm{N}_{\mathrm{s}}$ & 36 & 36 & 36 \\
\hline
\end{tabular}

\section{SIMULATION OF THE PROPOSED MODEL}

Figure 3 represents the main system. Input variables are Temperature and Irradiance when output variables are Current delivered by the module and power generated to be used by load either in stand alone or grid connected mode. Figure 4 is a subsystem of the main system. It is an implementation of (6). It is used to simulate the proposed model by incrementing $\mathrm{R}_{\mathrm{s}}$ until matching $P_{m p}$ with $P_{m p, e x}$. The experimental data for maximum power at STC provided by the manufacturer of PWX 500 PV module $(49 \mathrm{~W})$ are given in Table 1.

To valid our model, the PV module is simulated under Matlab-Simulink. The general diagram is given in Figure 5. It comprises of a PV module and a resistive load in parallel. A diode is connected in series to prevent the reverse current flow. To make the voltage stable, a filter is connected before the load. A converter is used to boost voltage. Its gate is controlled by the output of MPPT (Maximum Power point Technique) bloc in order to get the max of the power delivered by the PV module.

One of the most used methods of algorithms in MPPT is Perturb and Observe commonly called $(\mathrm{P} \& \mathrm{O})$. It consists on making a perturbation in the voltage and observing the rate of change of power. It depends on the position of the optimum point to adjust the reference voltage [20]. A flowchart of $\mathrm{P} \& \mathrm{O}$ method is presented in Figure 6.

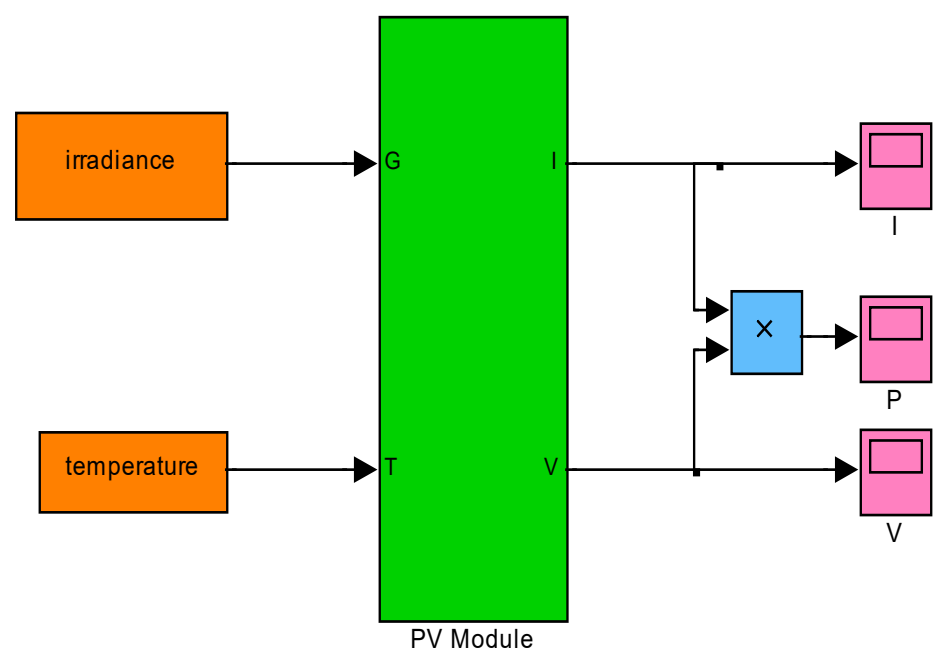

Figure 3. Presentation of the whole PV model 


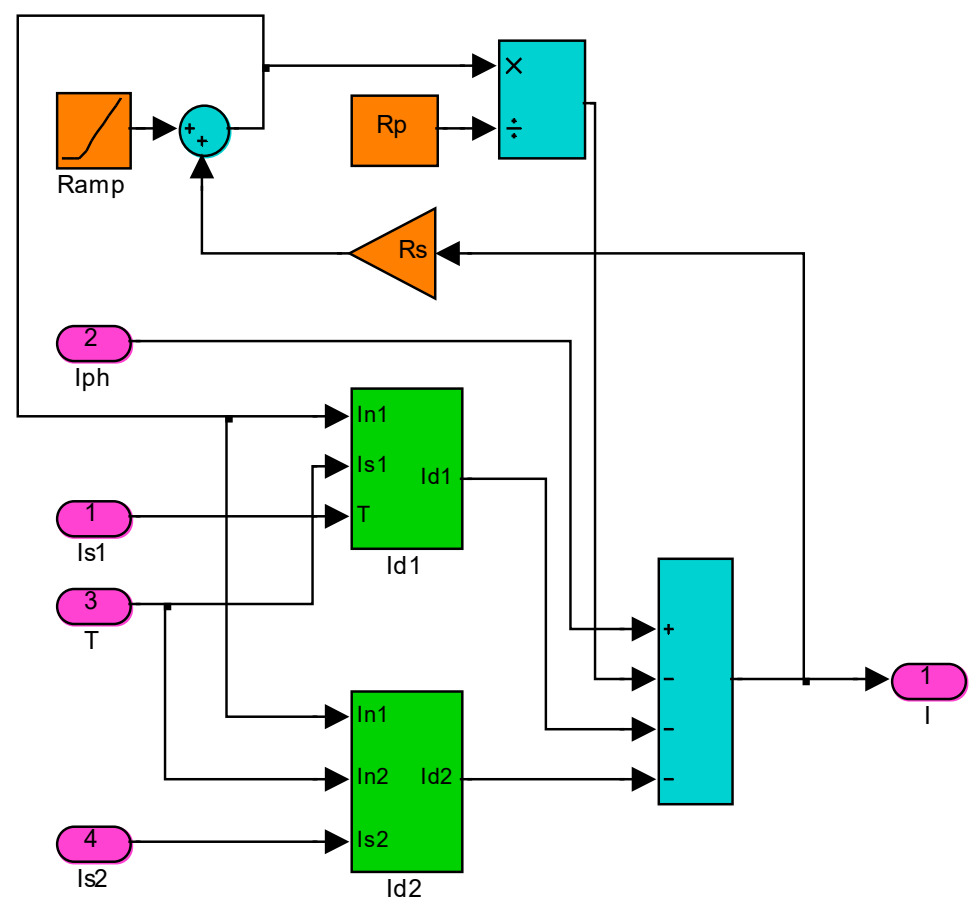

Figure 4. Detailed Two Diode model with $R_{P}$

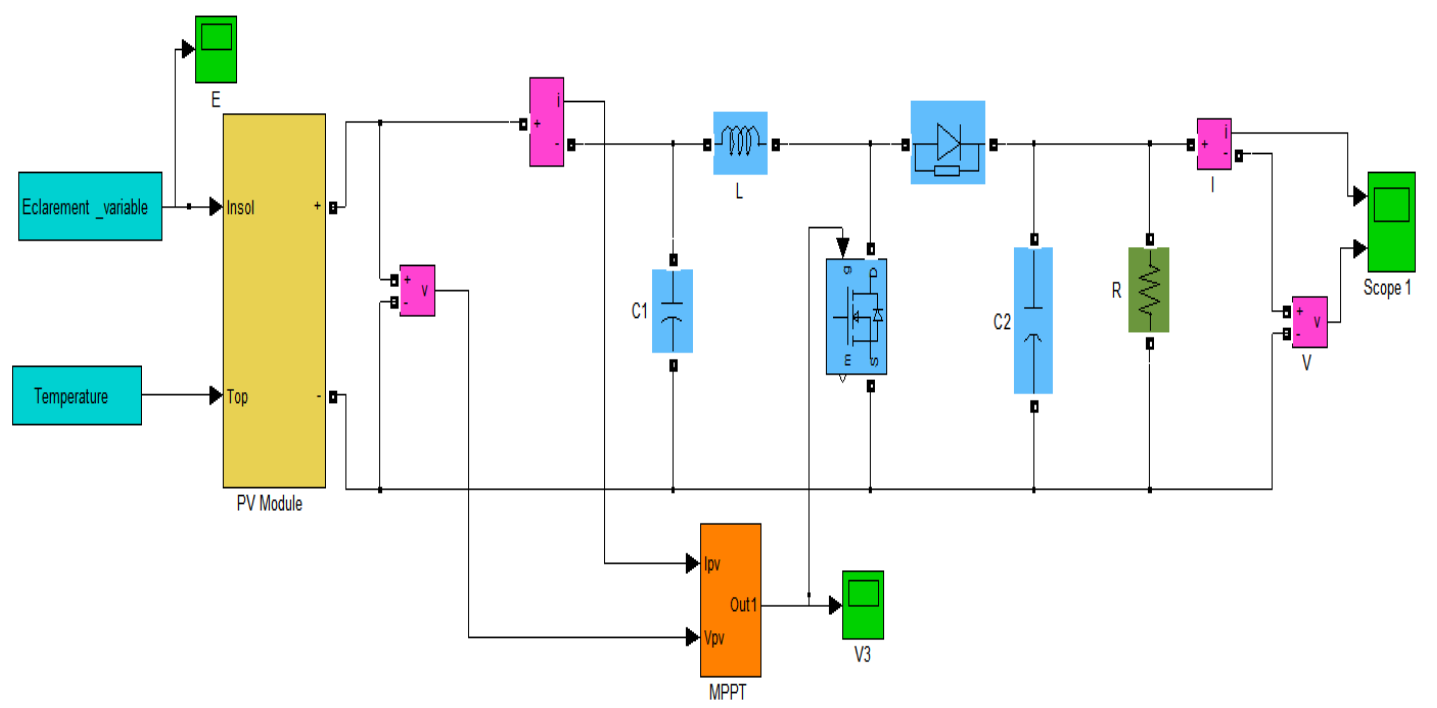

Figure 5. General diagram of Photovoltaic system connected to a resistive load 


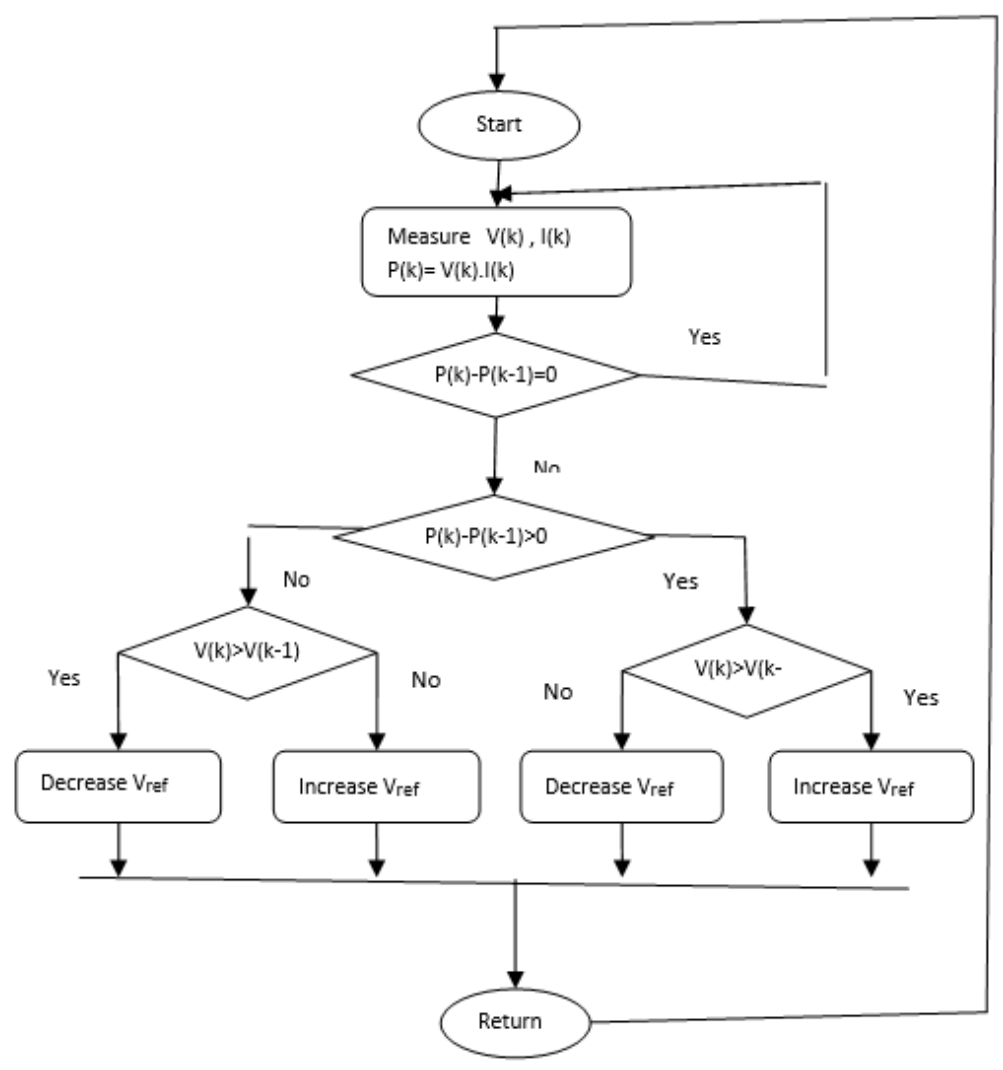

Figure 6. The flowchart of $\mathrm{P} \& \mathrm{O}$ algorithm

The duty cycle can control the DC/DC converter and maintain the voltage at the maximum. The diagram of Figure 7 taken from references [21] and [24] presents a part of our main system concerning the DC/DC converter built a high frequency IGBT switch. Authors give equations of inductor (L), capacitor (C) and the duty cycle (D):

$$
L=\frac{v_{\text {int }} \cdot D \cdot T}{\Delta i_{L}} ; \quad C=\frac{V_{\text {in }} \cdot D \cdot T}{\Delta V_{0} \cdot R \cdot f} ; D=\frac{V_{\text {out }}-V_{\text {in }}}{V_{\text {out }}}
$$

Where here, $\Delta i_{L}$ indicates inductor ripple current and $\Delta V_{0}$ indicates capacitor voltage ripple, $T$ is the time period (sec) and $f$ the switching frequency $(\mathrm{Hz})$

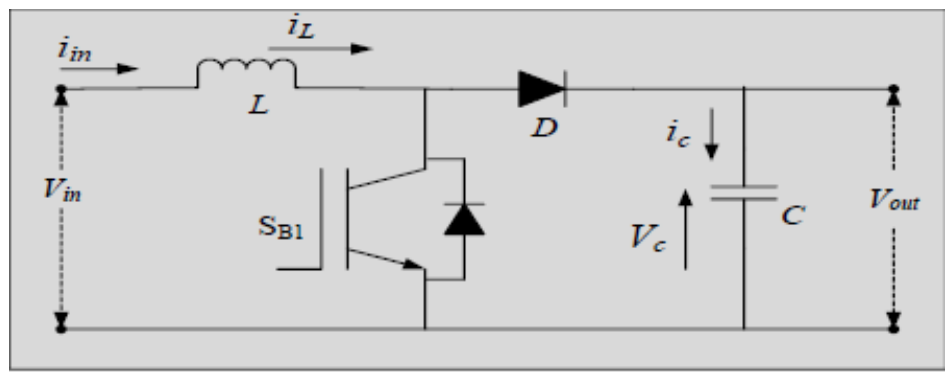

Figure 7. Circuit Diagram for Boost Converter [21, 24] 


\section{RESULTS AND ANALYSIS}

In a previous work [19], the One Diode $R_{P}$ model was modeled and simulated under Matlab environment. The series resistance $\mathrm{R}_{\mathrm{S}}$ was adjusted to $0.45 \Omega$ instead of $0.55 \Omega$ provided by manufacturer and the parallel resistance was computed iteratively and equal to $\mathrm{R}_{\mathrm{P}}=310 \Omega$ (not provided). The module PWX 500 (49W) was used to validate results. In the present work, the same method is used to adjust $\mathrm{R}_{\mathrm{S}}$ and compute $\mathrm{R}_{\mathrm{P}}$ for the Two Diode Model. Adjusted and computed parameters are summarized in Table1.

$\mathrm{R}_{\mathrm{S}}$ is iteratively increased and $\mathrm{R}_{\mathrm{P}}$ is simultaneously computed. The iterative method gave $\mathrm{R}_{\mathrm{S}}=0.3 \Omega$ and $R_{P}=200 \Omega$. These two values make the two diode model most representative for the chosen PV module. To simulate any other PV module, one can introduce in the (19) the respective experimental maximum power and then, the iterative method is used to determine the appropriate pair $\left(R_{S}, R_{P}\right)$ which makes the model the most representative.

After running simulation for some different values of $\mathrm{R}_{\mathrm{S}}, \mathrm{I}-\mathrm{V}$ curves of are represented in Figure 8, and $\mathrm{P}-\mathrm{V}$ in Figure 9. One can say in Figure 8, that the shape moves to the rectangular form when $\mathrm{R}_{\mathrm{s}}$ decreases. $I_{s c}$ and $V_{o c}$ are not affected by change of $R_{S}$, so the fill factor which is given by (12) change only with $P_{m p}$ :

$$
F F=\frac{P_{m p}}{V_{o c} I_{S C}}
$$

This is in accordance with (11) where $P_{m p}$ is with respect of $\mathrm{R}_{\mathrm{S}}$ and $\mathrm{R}_{\mathrm{P}}$.

When comparing the One Diode model curves and the Two Diode model ones as shown in Figures 10 and 11 , one can say thatfor the first model, simulated curves match with experimental data at $\mathrm{R}_{\mathrm{S}}=0.45 \Omega$ and $\mathrm{R}_{\mathrm{P}}=310 \Omega$. For the second model, simulated curve match with experimental data at $R_{S}=0.3 \Omega$ and $R_{P}=200 \Omega$.

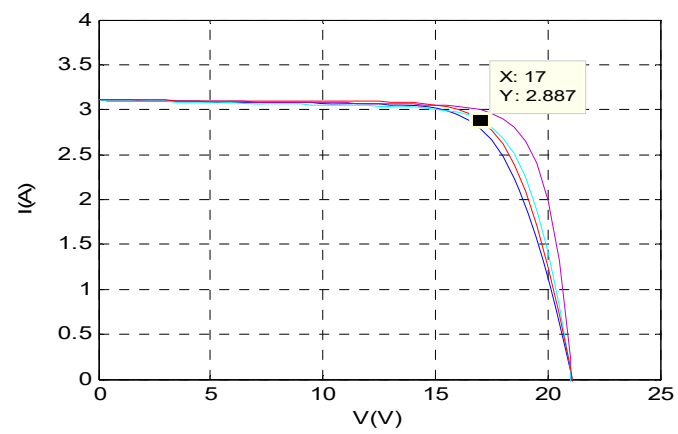

Figure 8. I (V) curves for different Rs (Two Diode model)

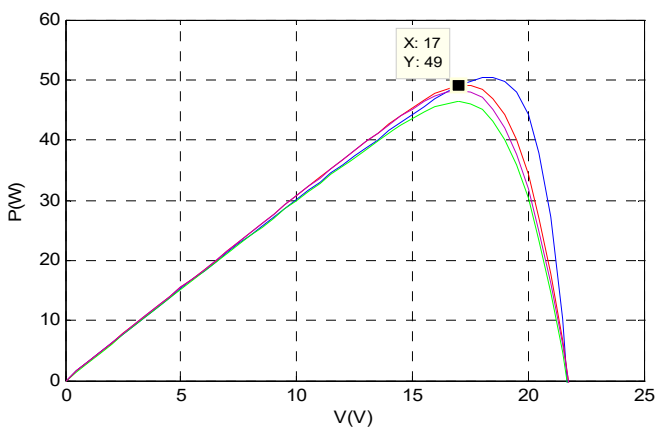

Figure 10. P (V) curves for different Rs (One Diode model)

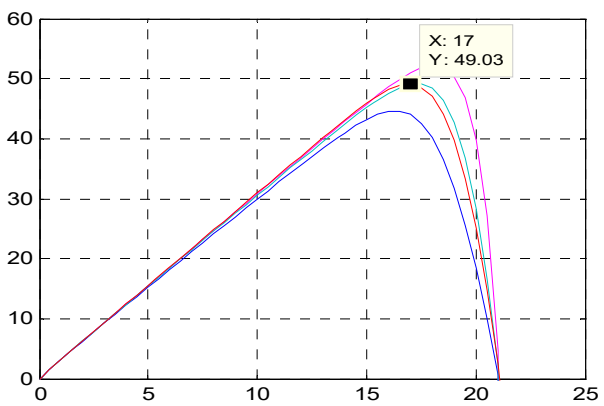

Figure 9. P (V) curves for different Rs (Two Diode model)

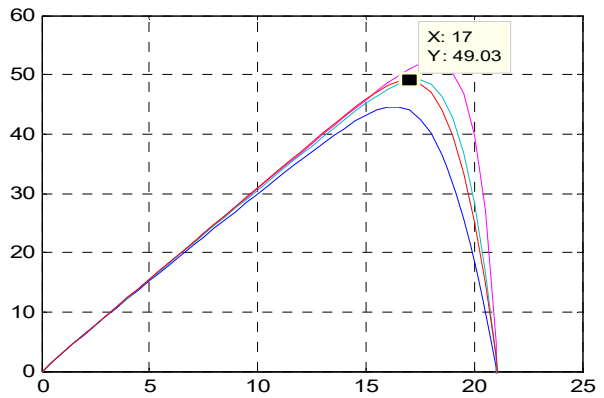

Figure 11. I (V) curves for different Rs (One Diode model) 
The proposed model can be used to simulate PV module at different levels of irradiance and temperature The I (V) and P (V) characteristics are respectively presented in Figure 12 and Figure 13, by varying irradiance from $200 \mathrm{~W} / \mathrm{m}^{2}$ to $1000 \mathrm{~W} / \mathrm{m}^{2}$ at $\mathrm{T}=25^{\circ} \mathrm{C}$. In Figure 13 and Figure 14 , The $\mathrm{I}(\mathrm{V})$ and $\mathrm{P}(\mathrm{V})$ characteristics are respectively presented by varying temperature from $0^{\circ} \mathrm{C}$ to $60^{\circ} \mathrm{C}$ at $\mathrm{G}=.1000 \mathrm{~W} / \mathrm{m}^{2}$. In Figure 14 and Figure 15, The I (V) and $\mathrm{P}(\mathrm{V})$ characteristics are respectively presented by varying temperature from $0^{\circ} \mathrm{C}$ to $60^{\circ} \mathrm{C}$ at $\mathrm{G}=.1000 \mathrm{~W} / \mathrm{m}^{2}$

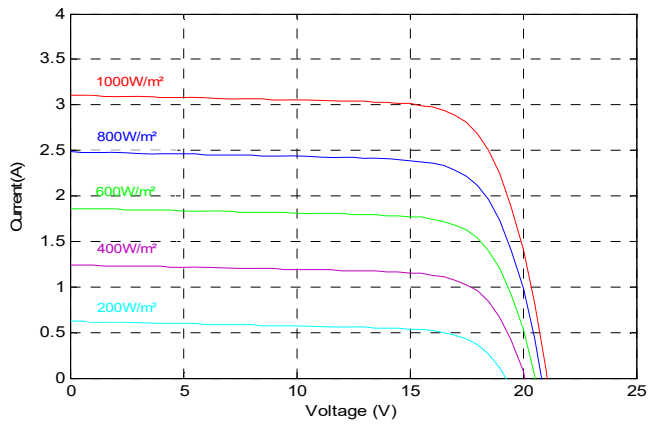

Figure 12. I (V) characteristics by varying irradiance at $\mathrm{T}=25^{\circ} \mathrm{C}$

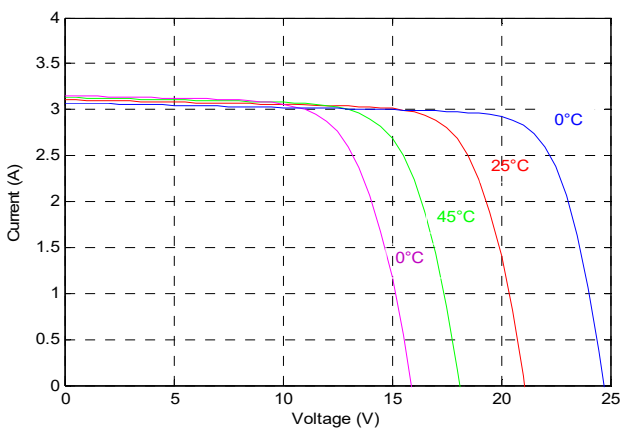

Figure 14. I (V) characteristics by varying temperature at $\mathrm{G}=1000 \mathrm{~W} / \mathrm{m}^{2}$

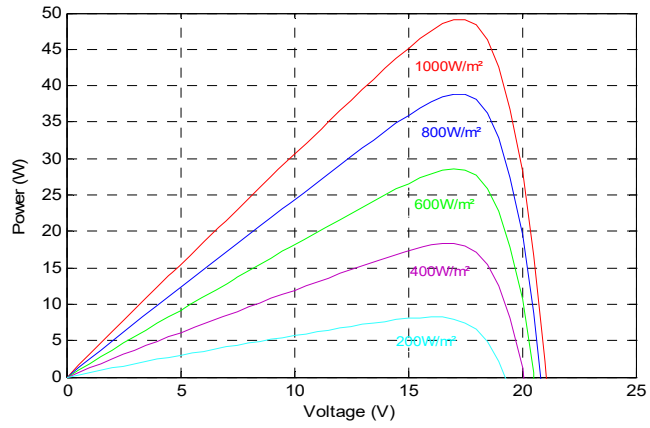

Figure 13. P (V) characteristics by varying irradiance at $\mathrm{T}=25^{\circ} \mathrm{C}$

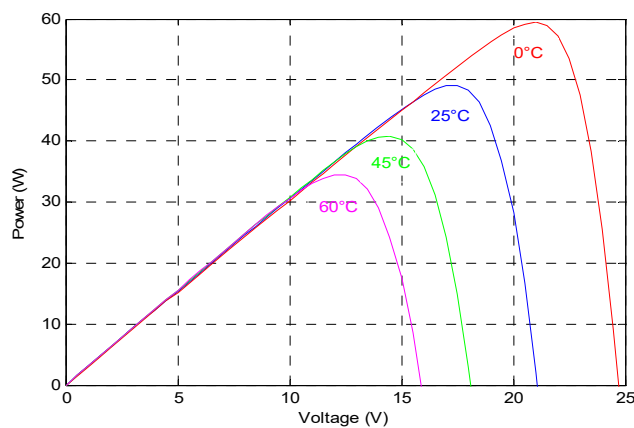

Figure 15. P (V) characteristics by varying temperature at $\mathrm{G}=1000 \mathrm{~W} / \mathrm{m}^{2}$

The next step of the work is to use the proposed model in the topology presented in Figure 5. The one stage PV system adaptation is used to supply a resistive load. Since the one stage system is in continuous current mode, voltage and current at DC/DC converter (load side) are given by [22]. In the reference [23], the duty cycle $\mathrm{D}$ is taken as $\alpha$ and $\eta$ is the efficiency of the boost converter:

$$
\begin{aligned}
& V_{L}=\frac{V_{p v}}{1-D} \\
& I_{D}=\eta(1-D) I_{p v}
\end{aligned}
$$

Figure 15 shows the simulation of power delivered to the load by varying irradiance at $1 \mathrm{~s}$ from $400 \mathrm{~W} / \mathrm{m}^{2}$ to $1000 \mathrm{~W} / \mathrm{m}^{2}$ and from $1000 \mathrm{~W} / \mathrm{m}^{2}$ to $400 \mathrm{~W} / \mathrm{m}^{2}$ at $3 \mathrm{~s}$ in the general diagram is given in Figure 5 when using $\mathrm{P} \& \mathrm{O}$ algorithm. One can see that when varying irradiance, the power delivered to the load corresponds to the maximum power extracted to the module at each level according to the plots presented in Figure 13.

Int J Pow Elec \& Dri Syst, Vol. 10, No. 3, Sep 2019 : $1603-1612$ 


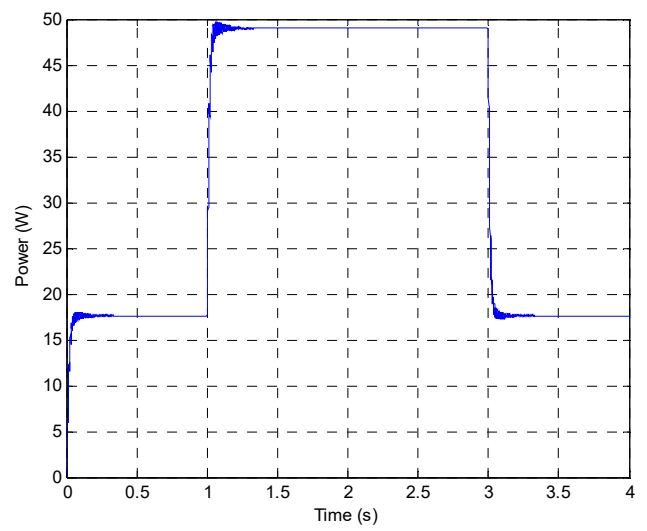

Figure 15 Power delivered to the load with P\&O method

\section{CONCLUSION}

In this paper, an accurate model of $\mathrm{PV}$ cell is presented in details and simulated under MATLAB/SIMULINK environment. Elaboration of the presented model is in accordance with the fundamentals of semi conductors and the technology of the PV cell. The computed parameters of the PV cell are chosen because of their variation with irradiance and temperature. This model can be used as a tool to study all type of PV modules available in markets even if manufacturers don't give all parameters. The series resistance $R_{S}$, is adjusted by increasing from zero and used to compute the parallel resistance in order to match the experimental maximum power point provided in data sheet with the computed one. In our case, a pair of $\left(\mathrm{R}_{\mathrm{S}}=0.3 \Omega, \mathrm{R}_{\mathrm{P}}=200 \Omega\right)$ instead of $\left(R_{S}=0.55 \Omega\right.$, and $R_{p}$ not provided $)$ is obtained and then to simulate and validate the proposed model. In a previous work, a single diode $\mathrm{R}_{\mathrm{P}}$ model was presented and this work about Two Diode Model is a new step. Then, the proposed model was simulated in a general diagram a resistive load via a continued bus. A DC/DC boost converter was used and controlled by an MPPT (Maximum Power Point Tracker) method. The chosen algorithm was P\&O because it's easily implemented. The accuracy of the proposed model is demonstrated by different plots which show that the power delivered to load match with the maximum power obtained from the PV module. In this work, the simplest form of load was used to explain and illustrate the proposed model. A possible future application of this model will be in grid connected PV system with a non linear load.

\section{REFERENCES}

[1] M. Venkatesan, R. Rajeswari, M. Kaliyamoorthy, M. Srithar, "Transient and Steady State Analysis of Modified Three Phase Multilevel Inverter for Photovoltaic System," International Journal of Power Electronics and Drive System (IJPEDS), vol. 8, no. 1, pp. 31, 2017.

[2] Z. Zerhouni,M H. Zerhouni, M. Zegrar, T. Benmessaoud, A B. Stanbouli and A. Midoun, "Proposed Methods to Increase the Output Efficiency of a Photovoltaic (PV) System," Acta Polytechnica Hungarica, vol. 7, no. 2, 2010.

[3] H. Abouobaida, S. El Bied, "Modeling and Control Design for Energy Management of Grid Connected Hybrid PVWind System," International Journal of Applied Power Engineering (IJAPE), vol. 7, no. 3, pp. 209 223, 2018.

[4] Q. Kou, S. A. Klein, W. A. Beckman, "A method For Estimating The Long-Term Performance Of Direct-Coupled Pv Pumping Systems," Solar Energy, vol. 64, no. 1, pp. 33-40, 1998.

[5] R. Chenni , M. Makhlouf, T. Kerbache, A. Bouzid, "A detailed modeling method for photovoltaic cells," Energy Elsevier, vol. 30. 2005.

[6] A. Abdulameer, A. Al-Khazzar, "Behavior of Four Solar PV Modules with Temperature Variation," International Journal of Renewable Energy Research, vol. 6, no. 3, 2016.

[7] B. Alsayid, J. Jallad," Modeling and Simulation of Photovoltaic Cells/Modules/Arrays," International Journal of Research and Reviews in Computer Science (IJRRCS), vol. 2, no. 6, 2011.

[8] Kashif Ishaque a, Zainal Salam a, Syafaruddin, "A comprehensive MATLAB Simulink PV system simulator with partial shading capability based on two-diode model," Solar Energy, vol. 85, no. 9, pp. 2217-2227, 2011.

[9] M. G. Villalva, J. R. Gazoli, E. Ruppert F, "Modeling and circuit-based simulation of photovoltaic arrays," Brazilian journal of power electronics, vol. 14, no. 1, pp. 35-45, 2009.

[10] W. De Soto, "Improvement And Validation Of A Model For Photovoltaic Array Performance," Solar Energy, vol. 80, no. 1, pp. 78-88, 2006.

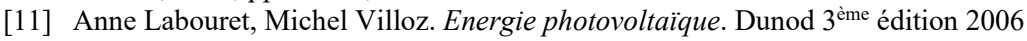


[12] E. Chahid, M. I. Oumhand, A. Malaoui, "A Fast Strategy to determine the Physical and Electrical Parameters of Photovoltaic Silicon Cell," International Journal of Applied Power Engineering (IJAPE), vol. 6, no. 2, pp. 104-113, 2017

[13] K . Ishaque, Z. Salam, "An Improved modeling method to determine the model parameters of photovoltaic PV modules using differential evolution DE," Solar Energy, vol. 85, no. 9, pp. 2349-2359, 2011.

[14] K. Ishaque, Z. Salam, H. Taheri, "Accurate MATLAB Simulink PV System Simulator Based on a Two-Diode Model," Journal of Power Electronics, vol. 11, no. 2, pp.179187, 2011.

[15] D. Bonkoungou, Z. Koalaga, D. Njomo, "Modelling and Simulation of photovoltaic module considering singlediode equivalent circuit model in MATLAB," International Journal of Emerging Technology and Advanced Engineering, vol. 3, no. 3, 2013.

[16] S. Bana, R.P. Saini, "A mathematical modeling framework to evaluate the performance of single diode and double diode based SPV systems," Energy Reports, elsevier, vol. 2, pp. 171-187, 2016

[17] S. Rißland, O. Breitenstein, "Considering the distributed series resistance in a two-diode model," Energy Procedia, vol. 38, pp $167-175,2013$.

[18] B. Alsayid, "Modeling and Simulation of Photovoltaic Cell/Module/Array with Two-Diode Model," International Journal of Computer Technology and Electronics Engineering (IJCTEE), vol. 2, no. 3, pp. 6-11, 2012.

[19] A. Habbati bellia, F. Moulay, "A detailed modeling of photovoltaic module using MATLAB," NRIAG Journal of Astronomy and Geophysics, vol. 3, no. 1, pp 53-61, 2014.

[20] H. Abou obaida, S. EL Beid, " Practical Performance Evaluation of Maximum Power Point Tracking Algorithms in A Photovoltaic System," International Journal of Power Electronics and Drive System (IJPEDS), vol. 8, no. 4, pp. 1744-1755, 2017.

[21] S. Khichar, Y. Gopal, M. Lalwani, "An Enhanced Control Strategy for the Stable Operation of Distributed Generation during Grid-connected and Islanded Mode," International Journal of Applied Power Engineering (IJAPE), vol. 7, no. 2, pp. 145-156, 2018.

[22] M.Makhlouf, F. Messai, H. Benalla, "Modeling and control of a single-phase grid connected photovoltaic system," Journal of Theoretical and Applied Information Technology, vol. 37 no. 2, pp. 289-296, 2012.

[23] M. Dris, B. Djilani, "Hybrid System Power Generation Wind-photovoltaic Connected to the Electrical Network 220 kV," International Journal of Applied Power Engineering (IJAPE), vol. 7, no.1, pp. 10 17, 2018.

[24] N. Prabaharn, K. Palanisamy, "Analysis and integration of multilevel inverter configuration with boost converters in a photovoltaic system," Energy Conversion and Management, vol. 128, pp. 327-342, 2016. 